\title{
Endogenous GUS-like activity in Capsicum chinense Jacq.
}

\author{
Laura Yesenia Solís-Ramos *\# \\ Unidad de Bioquímica y Biología Molecular de Plantas \\ Centro de Investigación Científica de Yucatán \\ Calle 43, No.130, Chuburná de Hidalgo \\ C.P. 97200 , Mérida, Yucatán, México \\ E-mail: laura.solisramos@ucr.ac.cr \\ Tomas González-Estrada \\ Unidad de Bioquímica y Biología Molecular de Plantas \\ Centro de Investigación Científica de Yucatán \\ Calle 43, No.130, Chuburná de Hidalgo \\ C.P. 97200 , Mérida, Yucatán, México

\section{Antonio Andrade-Torres} \\ INBIOTECA \\ Universidad Veracruzana \\ Apdo. postal 250, C.P. 91000, Xalapa, Veracruz, México \\ Gregorio Godoy-Hernández \\ Unidad de Bioquímica y Biología Molecular de Plantas \\ Centro de Investigación Científica de Yucatán \\ Calle 43, No.130, Chuburná de Hidalgo \\ C.P. 97200 , Mérida, Yucatán, México \\ Enrique Castaño de la Serna \\ Unidad de Bioquímica y Biología Molecular de Plantas \\ Centro de Investigación Científica de Yucatán \\ Calle 43, No.130, Chuburná de Hidalgo \\ C.P. 97200 , Mérida, Yucatán, México
}

Financial support: Consejo Nacional de Ciencia y Tecnología (CONACYT), México and Dirección de Intercambio Académico de la Secretaría de Relaciones Exteriores from México.

Keywords: Agrobacterium tumefaciens, $\beta$-glucuronidase, Capsicum chinense, gene uidA.

Present address: " Escuela de Biología, Universidad de Costa Rica, P.O. Box 11501-2060, San Pedro, Costa Rica. ${ }^{*}$ Consejo de Ciencia y Tecnología del Estado de Yucatán (CONCYTEY), Mérida, Yucatán, México.

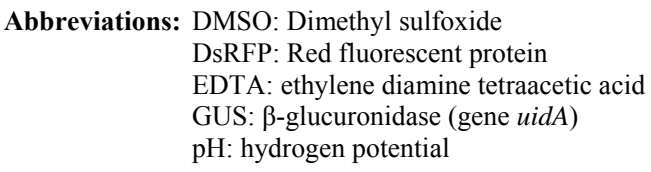

The gene uidA, codes for $\beta$-glucuronidase, which is one of the reporters more frequently utilized in transgenic plants. However, this can only be use if the selected organism does not present endogenous GUS-like activity. In tissues of $C$. chinense we found a GUS-like activity showing different levels of intensity. Histochemical screening showed that endogenous GUSlike activity decreased, or reduced significantly, in almost all tissues with exception of stament, when phosphate buffer was adjusted to $\mathrm{pH} 8$. Subsequently, $C$. chinense zygotic embryo explants were transient transformed with Agrobacterium tumefaciens LBA4404
(pCAMBIA2301) and plantlets regenerated were histochemically stained in phosphate buffer pH 8 . Observations of incubated tissues of $C$. chinense regenerants showed blue staining, suggesting expression of uidA. Incubated tissues of non-transformed regenerants did not show blue staining in phosphate buffer $\mathrm{pH} \mathrm{8.} \mathrm{The} \mathrm{results} \mathrm{show} \mathrm{that} \mathrm{for} \mathrm{transformation}$ experiments of $C$. chinense with uidA gene, $\mathrm{pH} 8$ is recommended for histochemical staining.

Habanero chili (Capsicum chinense Jacq.) is a species of economic importance to Mexico. The Capsicum genus is

*Corresponding author 
recalcitrant in in vitro morphogenesis protocols, complicating regeneration and genetic transformation (reviewed by Ochoa-Alejo and Ramírez-Malagón, 2001). C. chinense is no exception (Santana-Buzzy et al. 2005; López-Puc et al. 2006), and no efficient, reproducible regeneration system has yet been developed for this species. A dependable regeneration system is indispensable for genetic improvement, and is also important to conduct studies to establish a reliable genetic transformation protocol, as it can be an alternative to abate recalcitrance of tissues to in vitro regeneration, besides being a useful tool for genetic improvement (Zuo et al. 2002; Solís-Ramos et al. 2009).

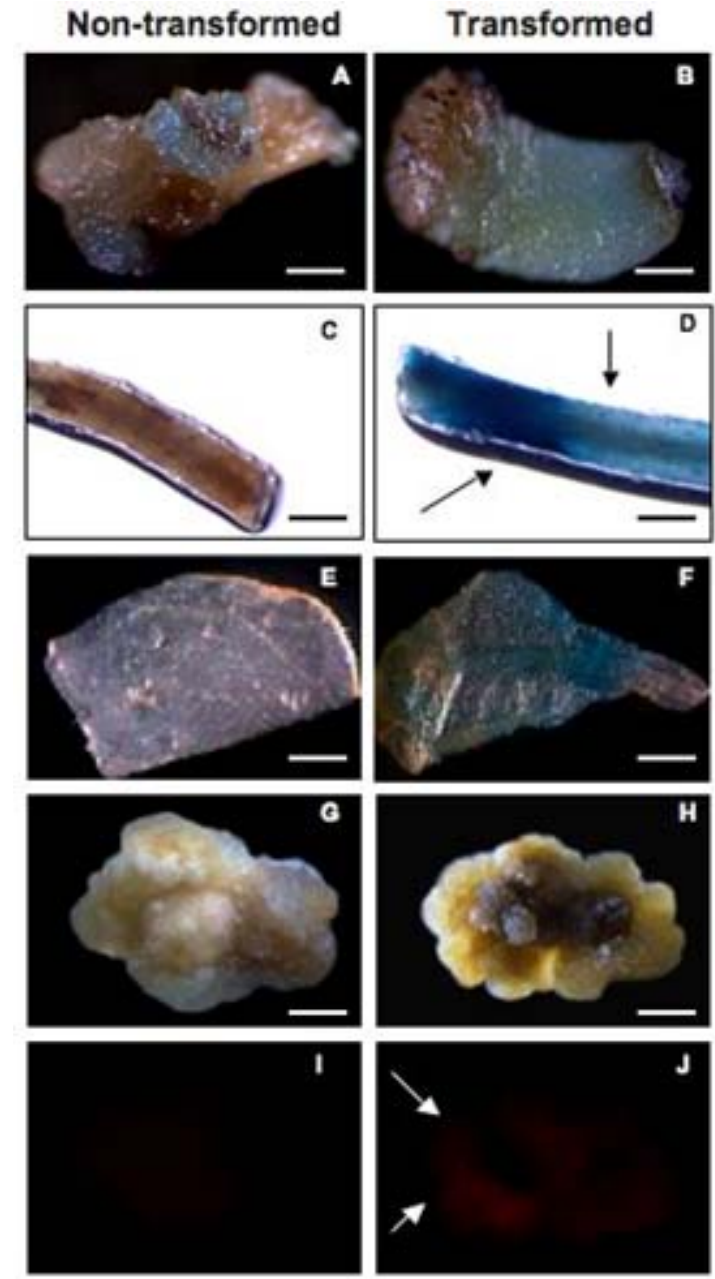

Figure 1. GUS histochemical staining in phosphate buffer pH 7 in transformed of Capsicum chinense and Nicotiana tabacum with uidA reporter gene.

A-B: C. chinense non-transformed andtransformed calli. C-D: C. chinense non-transformed and transformed stem. E-F: N. tabacum non-transformed and transformed leaf explant.

G-J: micrographs under visible and fluorescent light of nontransformed ( $\mathrm{G}$ and $\mathrm{I})$ and transformed $(\mathrm{H}$ and $\mathrm{J}) \mathrm{C}$. chinense calli.

$\mathrm{J}$ : expression of DsRFP observed in a transformed callus. Horizontal bars from A-B: $0.1 \mathrm{~cm}, \mathrm{C}-\mathrm{F}: 0.5 \mathrm{~cm}$ and G-J: 0.2 $\mathrm{cm}$.
The gene uidA codes for $\beta$-glucuronidase which is utilized as a reporter in plant genetic transformation because it is generally believed that higher plants do not show GUS-like endogenous activity (Jefferson, 1987; Martin et al. 1991; Sudan et al. 2006). However, several studies have demonstrated that some plant species show endogenous GUS-like activity in vegetative tissues as well as reproductive organs (Cervera, 2005; Sudan et al. 2006).

The enzyme stability and high sensitivity of the GUS assay to qualitative (histochemical assay) and to quantitative (fluorometric or spectrophotometric assay) detection are some of the reasons that explain the extensive use of uidA gene in plant genetic transformation (Cervera, 2005).

Therefore, in order to avoid undesirable effects in interpreting genetic transformation results, it is recommended to evaluate potential endogenous GUS-like activity in tissues that will be targeted to genetic transformation by using uidA as a reporter. The $\mathrm{pH}$ of the assay buffer is very critical for detection of the GUS activity in plants. The E. coli-derived GUS has optimum activity at $\mathrm{pH} 7.0$ and hence plant tissues are assayed at neutral $\mathrm{pH}$ after transformation (Sudan et al. 2006).

The histochemical staining of plant tissues for GUS activity has some disadvantages, such as a high degree of difficulty to detect activity when gene expression is low or in cases when optical density of plant tissues is high. In order to allow a better visualization of blue staining in transformed plants, it is recommended that green tissues must be treated with ethanol to eliminate chlorophylls (Rech et al. 2003).

The aim of this study was to genetically transform Capsicum chinense Jacq. via Agrobacterium tumefaciens (1) to characterize GUS activity in transformed and nontransformed tissues, (2) to evaluate the effect of $\mathrm{pH}$ level of phosphate buffer on the endogenous GUS-like activity of non-transformed tissues, and provide means of distinguishing between the two activities in different tissues of $C$. chinense.

\section{MATERIALS AND METHODS}

\section{Transient genetic transformation of zygotic embryo explants via Agrobacterium tumefaciens}

Segments of mature zygotic embryos of $C$. chinense were used as explants for transient transformation with $A$. tumefaciens LBA4404 (pCAMBIA2301) and C58C1 (pER10W-35S Red). T-DNA in pCAMBIA2301 (Center for the Application of Molecular Biology to International Agriculture, Canberra, Australia) includes a copy of Escherichia coli uidA gene under the control of CaMV35S promoter and the NOS terminator. In addition, T-DNA contains the neomycin phosphotranspherase II gene (npt) flanked by the CaMV35S promoter and the CaMV35S terminator. In this binary vector, uidA gene coding sequence is interrupted by a Castor Bean catalase intron, 
which has to be removed for eukaryotic expression and prevents bacterial transcriptions of the gene coding sequence.

The disarmed A. tumefaciens $\mathrm{C} 58 \mathrm{C} 1$ carrying the binary vector pER10W-35S Red (Canche-Moo et al. 2006) was used to transform C. chinense (Solís-Ramos et al. 2009) as control for transformation efficiency. The binary vector pER10W-35S Red, contains the DsRFP reporter gene under the $35 \mathrm{~S}$ constitutive promoter, and the gene WUSCHEL under an $17 \beta$-estradiol inducible promoter (Zuo et al. 2002).

Transient transformation of $C$. chinense explants and plant regeneration were carried out following the protocol previously described by Solís-Ramos et al. (2009). In addition, as a positive control leaves explants of Nicotiana tabacum were transient transformed via $A$. tumefaciens LBA4404 (pCAMBIA2301), to verify that the protocol used for GUS activity was done properly.

\section{Histochemical staining for $\beta$-glucuronidase activity}

Histochemical staining of $C$. chinense explants was carried out following a protocol reported by Jefferson (1987) with modifications. Explants were vacuum infiltrated for $5 \mathrm{~min}$ in a phosphate buffer solution consisting of $100 \mathrm{mM}$ $\mathrm{NaH}_{2} \mathrm{PO}_{4}, 10 \mathrm{mM}$ EDTA, $0.5 \mathrm{mM}$ potassium ferricyanide $\mathrm{K}_{3} \mathrm{Fe}(\mathrm{CN})_{6}, 0.5 \mathrm{mM}$ potassium ferrocyanide $\mathrm{K}_{4} \mathrm{Fe}(\mathrm{CN})_{6}$
$3 \mathrm{H}_{2} \mathrm{O}$, and $0.2 \%$ triton X-100. X-Gluc (5-bromo-4-cloro-3 indolyl- $\beta$-D-glucuronide) previously dissolved in DMSO was added to a final concentration of $1 \mathrm{mg} / \mathrm{L}$.

Explants were dark incubated at $37^{\circ} \mathrm{C}$ for $24 \mathrm{hrs}$. After incubation, staining solution was eliminated and explants washed with $70 \%$ ethanol for $24 \mathrm{hrs}$ to eliminate chlorophylls and other pigments present in treated tissues. Explants were stored in fresh $70 \%$ ethanol.

Presence of blue spots was recorded and interpreted as transient GUS expression. A stereoscope (Leica MZLIII, Germany) was utilized for better visualization. Color photographs were taken with a digital camera attached to the stereoscope and connected to a PC. Analysis of variance at $\alpha=0.05$ was conducted with Sigma Stat for Windows (version 3.11) to identify statistical differences.

\section{Detection of transient red fluorescent protein activity}

The transient expression of red fluorescent protein was detected using a Leica MZFLIII stereoscopic microscope equipped with appropriate filtres $(546 / 10 \mathrm{~nm}, 600 / 40 \mathrm{~nm})$.

\section{$\mathrm{pH}$ effect on endogenous GUS-like activity in $C$. chinense}

We analyzed the $\mathrm{pH}$ effect on endogenous GUS-like activity in C. chinense, tissue explants from reproductive

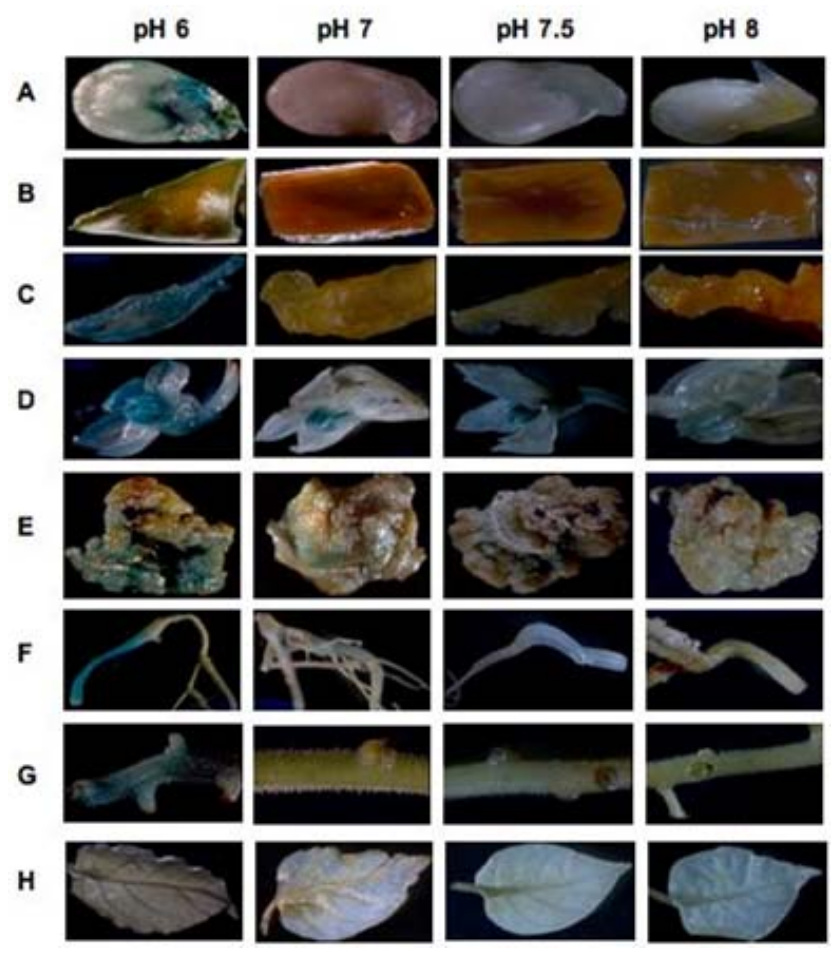

Figure 2. Screening of endogenous GUS-like activity in Capsicum chinense at different phosphate buffer pH values. A: zygotic embryo; B: pericarp; C: septum; D: flower; E: 30 d callus; F: 90 d root; G: 90 d stem and H: 90 d leaf. 
Table 1. Relative expression of endogenous GUS-like activity in tissues of Capsicum chinense Jacq at different pH. Small crosses indicate relative intensity of staining. The evaluation was repeated three times ever explant, showed the $100 \%$. $d=$ days.

\begin{tabular}{|l|c|c|c|c|}
\hline \multicolumn{1}{|c|}{ Tissue } & \multicolumn{3}{c|}{ pH } & 8.5 \\
\hline & 6 & 7 & + & - \\
\hline Zygotic embryo & +++++ & ++ & ++ & - \\
\hline Pericarp & +++ & - & + & + \\
\hline Septum & +++++ & +++ & - & - \\
\hline Stamens & +++++ & - & +++ & - \\
\hline Petals & - & +++++ & - & - \\
\hline Calli (30 d) & +++++ & +++ & - & - \\
\hline Root (90 d) & +++++ & - & - & - \\
\hline Stem (90 d) & +++++ & - & & + \\
\hline Leaves (90 d) & ++++ & & & + \\
\hline
\end{tabular}

organs of plants grown in a greenhouse were utilized as experimental biological material including zygotic embryo, pericarp, septum, petals and stamen. In addition, vegetative tissues including calli of 30 days, roots, stems and leaves of 90 days in vitro cultured plantlets.

To determinate in $C$. chinense tissues a condition to inhibit endogenous GUS-like activity identified when using the phosphate buffer at $\mathrm{pH} \mathrm{7,} \mathrm{a} \mathrm{set} \mathrm{of} \mathrm{experiments} \mathrm{were} \mathrm{carried}$ out by modifying phosphate buffer $\mathrm{pH}$ at $6,7,7.5$ and 8 , there were 3 replicates per treatment. Incubation conditions were followed as previously described and the number of stained explants was recorded. The relative expression of endogenous GUS-like activity in tissues of $C$. chinense, at different $\mathrm{pH}$ levels was evaluated. The endogenous GUSlike activity was defined by visual observation of the blue color provided by the staining protocol, to the higher intensity the greater number was assigned.

\section{Histochemical staining of regenerants in phosphate buffer pH 8}

Zygotic embryo explants of $C$. chinense were transient transformed in vitro with $A$. tumefaciens LBA4404 (pCAMBIA2301) following a procedure reported by SolísRamos et al. (2009). In vitro regenerated plantlets were stained in phosphate buffer $\mathrm{pH}$. Leaf explants of $N$. tabacum transformed plants via A. tumefaciens LBA4404 (pCAMBIA 2301) were included as a control for GUS staining at $\mathrm{pH} 8$.

\section{RESULTS}

GUS-activity and GUS-like activity in transient transformed and non-transformed zygotic embryo explants

Successful transient transformed C. chinense zygotic embryo explants were achieved with $A$. tumefaciens LBA4404 (pCAMBIA2301) and the bacteria were eliminated with $1 \mathrm{~g} / \mathrm{L}$ cefotaxime and $500 \mathrm{mg} / \mathrm{L}$ timentin (Solís-Ramos et al. 2009). The calli of $C$. chinense transient transformed with pER10W-35S Red (used as control for transformation efficiency) expressed the red fluorescent protein (DsRFP) (Figure 1J), but not the non-transformed calli (Figure 1I).

Developing calli from transient transformed explants (LBA4404 pCAMBIA2301) showing no bacteria incidence after 30 days in vitro culture, showed positive GUSstaining at $\mathrm{pH} 7$ (Figure 1B). Similarly, the nontransformed leaf tissue and the non-transformed developing calli, showed endogenous GUS-like activity in phosphate buffer $\mathrm{pH} 7$ (Figure 1A). Stem segments of seedlings of $C$. chinense grown in vitro and transient transformed with the uidA gene, showed GUS activity (Figure 1D), while the non-transformed stem segments showed no GUS activity (Figure 1C). We show results with $N$. tabacum as a control to verify that the protocol used for GUS activity was done properly (Figure 1E-F). 


\section{Non-transformed}
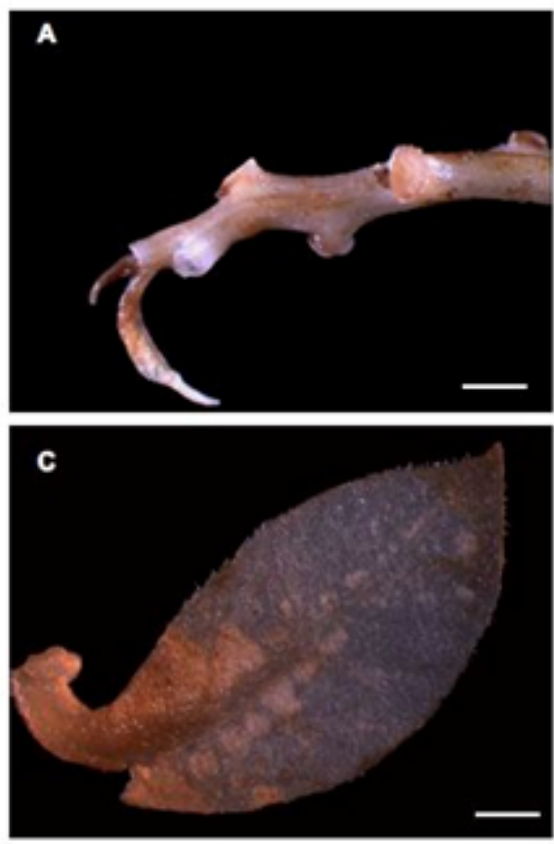

Transformed
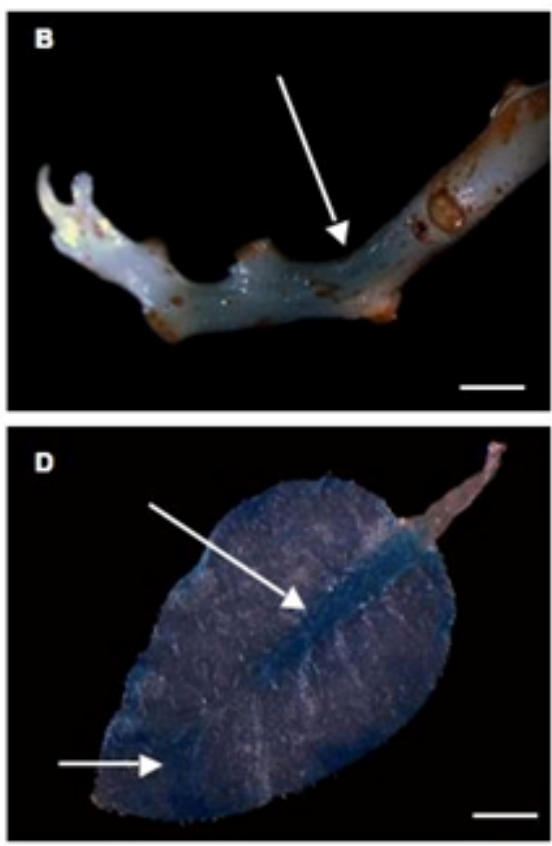

Figure 3. GUS histochemical staining in phosphate buffer pH 8 of Capsicum chinense and $N$. tabacum transformed with uidA reporter gene.

A: C. chinense non-transformed stem.

B: C. chinense stem transformed via A. tumefaciens LBA4404 (pCAMBIA2301).

C: N. tabacum non-transformed leaf.

D: N. tabacum transformed leaf via A. tumefaciens LBA4404 (pCAMBIA2301).

Horizontal bars from A-B: $0.5 \mathrm{~cm}, \mathrm{C}-\mathrm{D}: 0.2 \mathrm{~cm}$.

Analysis of variance did not report significant differences among transformed $(\mathrm{p}=0.622)$ and non-transformed explants $(\mathrm{p}=0.242)$ at $\mathrm{pH}$ 7. Therefore, GUS-staining at $\mathrm{pH} 7$ of $C$. chinense calli developed from zygotic embryo explants did not allow to differentia between putative $A$. tumefaciens transformed and non- transformed tissues.

\section{$\mathrm{pH}$ effect on endogenous GUS-like activity in $C$. chinense}

The endogenous GUS-like activity in C. chinense tissues was defined by visual observation of the blue color provided by the staining protocol the higher the intensity. A screening for endogenous GUS-like activity in C. chinense tissues was performed in phosphate buffer adjusted to $\mathrm{pH} 6$, 7, 7.5 and 8 (Figure 2 and Table 1). At pH 6 the $100 \%$ of all samples (vegetative and reproductive tissues) presented endogenous GUS-like activity. We should point that the triplicate foliar tissue tested only presented activity in vascular vessels (Figure 2H).

In phosphate buffer $\mathrm{pH} 7$ an intense GUS-like activity was observed in the $100 \%$ of stamen, calli and roots developing from in vitro cultivated zygotic embryo explants (Figure $2 \mathrm{D}, \mathrm{E}$, and F). In segments of zygotic embryo (non-in vitro cultivated), and pericarp (external layers) a less intense endogenous GUS-like activity was observed (Figure 2 A and B). In contrast, the $100 \%$ of septum, petals, stems and mature leaves of 90 days culture did not present endogenous GUS-like activity (Figure 2 C, D, G and H).

At $\mathrm{pH} 7.5$ no GUS-like activity was observed in all of the petals, root, stem or leaves (Figure $2 \mathrm{D}, \mathrm{F}, \mathrm{G}$ and $\mathrm{H}$ ). However, in septum, stamen and calli some GUS-like activity was observed (Figure $2 \mathrm{C}, \mathrm{D}$ and E).

A substantial decrease, or even a total absence, of GUS-like activity was observed in phosphate buffer $\mathrm{pH} 8$ in almost all tissue analyzed with an exception for a slight activity in stamens (Figure 2-D).

\section{Histochemical screening at $\mathrm{pH} 8$ of transient transformed regenerants}

From C. chinense zygotic embryos transient transformed plants were regenerated in vitro (Solís-Ramos et al. 2009), and were evaluated by histochemical staining using the phosphate buffer at $\mathrm{pH} 8$ (Figure 3). As a control test was also assessed leaf tissue of $N$. tabacum transformed and non-transformed (Figure $3 \mathrm{C}-\mathrm{D}$ ).

C. chinense stem segments of in vitro regenerated plantlets from transient transformed explants showed positive blue staining (Figure $3 \mathrm{~B}$ ). Leaves of transformed N. tabacum 
utilized as a control, showed GUS activity which verified that the protocol used for GUS activity was done properly (Figure $3 \mathrm{D}$ ). In contrast, tissues of $C$. chinense and $N$. tabacum regenerated from non-transformed explants did not show GUS or GUS-like activity at $\mathrm{pH} 8$ (Figure $3 \mathrm{~A}$ and C). Figure 3 shows that use of phosphate buffer at $\mathrm{pH} 8$ in tests, does not affect the activity of the uidA gene in transient transformed tissues of $C$. chinense. These results suggest that uidA gene is transcriptional active in $C$. chinense and $N$. tabacum tissues of plantlets regenerated from Agrobacterium-mediated transient transformed explants.

\section{DISCUSSION}

Previous reports of plant genetic transformation utilized reporter genes to determine whether the transformation method allowed incorporation of the transgen into the genome of interest. The uidA gene that codes for $\beta$ glucuronidase is one of de most frequently reporter gene utilized in plant transformation experiments (Cervera, 2005).

In this study zygotic embryo segments of $C$. chinense were transient transformed with A. tumefaciens LBA4404 (pCAMBIA2301) and then histochemically stained in phosphate buffer $\mathrm{pH} 7$ for GUS activity after 30 days of in vitro culture. Blue staining was observed in both transient transformed and non-transformed explants (Figure $1 \mathrm{~A}, \mathrm{~B}$ ). This result suggested an endogenous GUS-like activity in C. chinense calli. In addition, we observed endogenous GUS-like activity in pericarp, stamen, and 30 days calli, and 90 days roots of plantlets cultivated in vitro (Figure 2 $\mathrm{B}, \mathrm{D}, \mathrm{E}$ and $\mathrm{F}$ ).

These findings coincide with results reported for other species such as Ricinus communis L. that showed GUS-like activity in reproductive tissues (Rezmer et al. 1999, Cervera, 2005). However in pollen obtained from the in vitro flowers of $C$. frutescens inoculated with $A$. tumefaciens was observed transient GUS expression (Sharma et al. 2008).

In contrast, other reported species such as Bixa orellana (Zaldívar-Cruz et al. 2003), Cucurbita maxima L., Vicia faba L., Kalanchoe daigremontiana (Rezmer et al. 1999), Lycopersicon esculentum (Sun et al. 2006), Musa acuminata cv. "Grand Nain" scalps (Acereto-Escoffié et al. 2005) and Argemone mexicana L. (Godoy-Hernández et al. 2008), did not show endogenous GUS-like activity in evaluated tissues.

An important prerequisite in order to utilize a reporter gene, is the absence of endogenous activity in the target organism for transformation (Martin et al. 1992). In Arabidopsis thaliana it was reported that $\mathrm{pH}$ of the staining solution had a strong influence in endogenous GUS-like activity (Martin et al. 1992). Furthermore, endogenous GUS-like activity at $\mathrm{pH}$ lower than 7 can be inhibited with $20 \%$ methanol in the incubation buffer (Rezmer et al. 1999). Based on the previous results and reports, we decided to determine the effect of $\mathrm{pH}$ on the endogenous GUS-like activity identified in C. chinense by modifying $\mathrm{pH}$ of phosphate buffer.

In our experiments all evaluated tissues of $C$. chinense at pH 6 showed endogenous GUS-like activity (Figure 2 A$\mathrm{G})$, which is in agreement with previous reports for a wide variety of plant species that presented endogenous GUSlike activity at acidic $\mathrm{pH}$ in the staining buffer (Martin et al. 1992; Rezmer et al. 1999). The $\mathrm{pH}$ of the assay buffer was found to be critical with $\mathrm{pH} 4.0$ being optimum for detection endogenous GUS-like activity, recently were demonstrated ubiquitous in the tissues (vegetative as well as reproductive) root, stem, leaves and flowers of model plant species Arabidopsis thaliana, Oryza sativa, Nicotiana tabacum and Zea mays (Sudan et al. 2006).

However, by increasing $\mathrm{pH}$ to alkaline values in the staining solution the endogenous GUS-like activity was suppressed in most of the $C$. chinense tissues with the exception of stamen (Figure 2D).

By culturing in vitro we regenerated plantlets from zygotic embryo segments transient transformed by A. tumefaciens, which were histochemically stained in phosphate buffer $\mathrm{pH}$ 8 (Figure 3), the transient transformed regenerants showed blue staining, in contrast, non-transformed regenerants did not show any blue staining under the same staining conditions. This observed GUS activity in C. chinense tissues transformed by A. tumefaciens could be due to uidA expression, successfully inserted in the plant genome (Figure 3B). However, the genetic transformation of the $C$. chinense tissues is considered as transient, therefore only parts of the tissues are transformed which is shown in Figure $3 \mathrm{~B}$ and it is typical of transient transfections.

A false positive bacterial gene expression is discarded since pCAMBIA2301 includes an intron that interrupts the GUS coding sequence and prevents bacterial transcriptions of the gene coding sequence. GUS activity was also observed in $N$. tabacum foliar tissue excised of regenerated explants that were transformed by A. tumefaciens (Figure 3D). Nontransformed negative controls regenerated plants did not show GUS activity in staining buffer $\mathrm{pH} 8$ (Figure 3C).

Our results of histochemical staining in phosphate buffer $\mathrm{pH} 8$, suggest that uidA gene was introduced in regenerants of C. chinense and $N$. tabacum and the gene was transcriptional active as it can be inferred from the blue stain observed in tissues of regenerated plantlets. Additional characterization of regenerants will be conducted to verify by molecular methods these staining results.

The main problem during initial steps of transformation is just to get an assay conditions which can provide an initial screening. This problem has been solved by adjusting the $\mathrm{pH}$ to 8 for $C$. chinense. 


\section{ACKNOWLEDGMENTS}

The first author thanks to Dirección de Intercambio Académico of Secretaría de Relaciones Exteriores from México for scholarship and Centro de Investigación Científica de Yucatán for facilities and laboratory support. We wish to thank Q.F.B. Elidé Avilés Berzunza and I.I.A. Wilma González Kantún for technical help.

\section{REFERENCES}

ACERETO-ESCOFFIÉ, P.O.M.; CHI-MANZANERO, B.H.; ECHEVERRÍA-ECHEVERRÍA, S.; GRIJALVA, R.; KAY, A.J.; GONZÁLEZ-ESTRADA, T.; CASTAÑO, E. and RODRÍGUEZ-ZAPATA, L.C. Agrobacteriummediated transformation of Musa acuminata cv. "Grand Nain" scalps by vacuum infiltration. Scientia Horticulturae, July 2005, vol. 105, no. 3, p. 359-371.

CANCHE-MOO, R.; KU-GONZALEZ, A.; BURGEFF, C.; LOYOLA-VARGAS, V.; RODRIGUEZ-ZAPATA, L.C. and CASTAÑO, E. Genetic transformation of Coffea canephora by vacuum infiltration. Plant Cell Tissue and Organ Culture, March 2006, vol. 84, no. 3, p. 373-377.

CERVERA, Magdalena. Histochemical and fluorometric assays for uidA (GUS) gene detection. Chapter 14. In: PEÑA, Leandro ed. Transgenic plants: Methods and protocols. Humana Press, 2005, vol. 286, p. 203-213.

GODOY-HERNÁNDEZ, G.; AVILÉS-BERZUNZA, E.; CARRILLO-PECH, M. and VÁSQUEZ-FLOTA, F. Agrobacterium-mediated transient transformation of Mexican prickly poppy (Argemone mexicana L.). Electronic Journal of Biotechnology, January 2008, vol. 11, no. 1, p. 1-5.

JEFFERSON, Richard A. Assaying chimeric genes in plants: the GUS gene fusion system. Plant Molecular Biology Reporter, December 1987, vol. 5, no. 4, p. 387405.

LÓPEZ-PUC, Guadalupe; CANTO-FLICK, Adriana; BARRERDO-POOL, Felipe; ZAPATA-CASTILLO, Patricia; MONTALVO-PENICHE, María del C.; BARAHONA-PÉREZ, Felipe; SANTANA-BUZZY, Nancy and IGLESIAS-ANDREU, Lourdes. Direct somatic embryogenesis: a highly efficient protocol for in vitro regeneration of habanero pepper (Capscium chinense Jacq.). HortScience, December 2006, vol. 41, no. 7, p. 1645-1650.

MARTIN, T.; WOHNER, R.V.; HUMMEL, S.; WILLMITZER, L. and FROMMER, W.B. The GUS reporter system as a tool o study plant gene expression. In: GALLAGER, S. ed. GUS protocols. Academic Press, Inc. California, 1991, p. 23-43.

OCHOA-ALEJO, Neftali and RAMÍREZ-MALAGON, Rafael. In vitro chilli pepper biotechnology. In Vitro
Cellular \& Developmental Biology-Plants, November 2001, vol. 37, no. 6, p. 701-709.

RECH, Philippe; GRIMA-PETTENATI, Jacqueline and JAUNEAU, Alain. Fluorescence microscopy: a powerful technique to detect low GUS activity in vascular tissues. The Plant Journal, January 2003, vol. 33, no. 1, p. 205-209.

REZMER, Claudia; SCHLICHTING, Ralf; WÄCHTER, Rebecca and ULRICH, Cornelia. Identification and localization of transformed cells in Agrobacterium tumefaciens-induced plant tumors. Planta, October 1999, vol. 209, no. 4, p. 399-405.

SANTANA-BUZZY, Nancy; CANTO-FLICK, Adriana; BARAHONA-PÉREZ, Felipe; MONTALVO-PENICHE, María del Carmen; ZAPATA-CASTILLO, Patricia; SOLÍS-RUÍZ, Anabel; ZALDÍVAR-COLLÍ, Amílcar; GUTIÉRREZ-ALONSO, Omar and MIRANDA-HAM, Lourdes. Regeneration of habanero pepper (Capsicum chinense Jacq) via organogenesis. HortScience, October 2005 , vol. 40 , no. 6 , p. $1829-1831$.

SHARMA, A.; KUMAR, V.; GIRIDHAR, P. and RAVISHANKAR, G.A. Induction of in vitro flowering in Capsicum frutescens under the influence of silver nitrate and cobalt chloride and pollen transformation. Electronic Journal of Biotechnology, April 2008, vol. 11, no. 2, p. 1-6.

SOLÍS-RAMOS, L.Y.; GONZÁLEZ-ESTRADA, T.; NAHUATH-DZIB, S.; ZAPATA-RODRÍGUEZ, L.C. and CASTAÑO, E. Overexpression of WUSCHEL in C. chinense causes ectopic morphogenesis. Plant Cell, Tissue and Organ Culture, March 2009, vol. 96, no. 3, p. 279-287.

SUDAN, Charu; PRAKASH, Shiva; BHOMKAR, Prasanna; JAIN, Shalu and BHALLA-SARIN, Neera. Ubiquitous presence of $\beta$-glucuronidase (GUS) in plants and its regulation in some model plants. Planta, September 2006, vol. 224 , no. 4 , p. 853-864.

SUN, Hyeon-Jin; UCHII, Sayaka; WATANABE, Shin and EZURA, Hiroshi. A highly efficient transformation protocol for micro-Tom, a model cultivar for tomato functional genomics. Plant and Cell Physiology, March 2006, vol. 47, no. 3, p. 426-431.

ZALDÍVAR-CRUZ, J.M.; BALLINA-GÓMEZ, H.; GUERRERO-RODRÍGUEZ, C.; AVILÉS-BERZUNZA, E. and GODOY-HERNÁNDEZ, G.C. Agrobacteriummediated transient transformation of annatto (Bixa orellana) hypocotyls with the gus reporter gene. Plant Cell, Tissue and Organ Culture, June 2003, vol. 73, no. 3, p. 281-284.

ZUO, Jianru; NIU, Qi-Wen; FRUGIS, Giovanna and CHUA, Nam-Hai. The WUSCHEL gene promotes vegetative-to-embryonic transition in Arabidopsis. The Plant Journal, May 2002, vol. 30, no. 3, p. 349-359. 